\title{
The Use of Palliative Performance Score in Patients with End- Stage Liver Disease
}

\author{
Drew Kotler, MD \\ Thomas Jefferson University \\ Mital Shah, MD \\ Thomas Jefferson University \\ Sheela S. Reddy, MD \\ Thomas Jefferson University \\ Jonathan M. Fenkel, MD \\ Thomas Jefferson University \\ John Liantonio, MD \\ Thomas Jefferson University \\ Follow this and additional works at: https://jdc.jefferson.edu/medposters \\ IPraxtopabe forsaddditiowall agythowsmmons \\ Let us know how access to this document benefits you
}

\section{Recommended Citation}

Kotler, MD, Drew; Shah, MD, Mital; Reddy, MD, Sheela S.; Fenkel, MD, Jonathan M.; Liantonio, MD, John; and Halegoua-De Marzio, MD, Dina, "The Use of Palliative Performance Score in Patients with End-Stage Liver Disease" (2017). Department of Medicine Posters. 11.

https://jdc.jefferson.edu/medposters/11

This Article is brought to you for free and open access by the Jefferson Digital Commons. The Jefferson Digital Commons is a service of Thomas Jefferson University's Center for Teaching and Learning (CTL). The Commons is a showcase for Jefferson books and journals, peer-reviewed scholarly publications, unique historical collections from the University archives, and teaching tools. The Jefferson Digital Commons allows researchers and interested readers anywhere in the world to learn about and keep up to date with Jefferson scholarship. This article has been accepted for inclusion in Department of Medicine Posters by an authorized administrator of the Jefferson Digital Commons. For more information, please contact: JeffersonDigitalCommons@jefferson.edu. 


\section{Authors}

Drew Kotler, MD; Mital Shah, MD; Sheela S. Reddy, MD; Jonathan M. Fenkel, MD; John Liantonio, MD; and Dina Halegoua-De Marzio, MD 


\section{ntroduction}

- Palliative Care services are often underutilized in patients with End-Stage Liver Disease (ESLD) and often only initiated at the end of life

- The Palliative Performance Score (PPS) is an important tool used in Palliative Care to assess functional status

- PPS has five functional dimensions: ambulation, activity level and evidence of disease, self-care, oral intake, and level of consciousness

- The aim of this study is to determine if there is a correlation between Model for End-Stage Liver Disease (MELD) score and PPS in ESLD patients

- MELD is used to predict mortality and to prioritize liver transplant allocation in ESLD patients

\section{Methods}

- A retrospective analysis was performed using a database of all the inpatient Palliative Care consults at our tertiary, urban liver transplant center from March 2006 to April 2015

- 294 of 4394 consults were for ESLD patients

- PPS from the Palliative Care consult and hospital length of stay were identified

- MELD-Na score was calculated from the day the consult was performed

- Patients with underlying liver malignancies and those without laboratory data for MELD-Na calculation were excluded

\section{Results}

- 110 ESLD patients met our inclusion criteria

- Average MELD-Na of these patients was 30 (95\% CI 28.1-31.8)

- Average PPS of these patients was found to be 23.7\% (95\% CI 21.0-26.4)

- Patients were stratified by PPS and an average MELD-Na score was calculated for each PPS (Table 1)

- 46 of the 110 ESLD patients (41.8\%) were found to have the lowest possible Palliative Performance Score of $10 \%$

- Patients with a PPS of $10 \%$ were found to have an in-hospital mortality of $69.3 \%$. All other patients with a PPS of $10 \%$ were discharged on hospice care

- The relationship between Palliative Performance Score and in-hospital mortality was also charted (Graph 1)

\begin{tabular}{|c|c|c|}
\hline & & \\
$\mathrm{N}$ & PPS & MELD average \\
\hline 46 & $10 \%$ & 31.6 \\
\hline 16 & $20 \%$ & 35.3 \\
\hline 22 & $30 \%$ & 28.8 \\
\hline 15 & $40 \%$ & 25.1 \\
\hline 9 & $50 \%$ & 23.6 \\
\hline 2 & $60 \%$ & 18.5 \\
\hline $\mathbf{1 1 0}$ & $\mathbf{2 3 . 7 0 \%}$ & $\mathbf{3 0}$ \\
\hline
\end{tabular}

\section{Results}

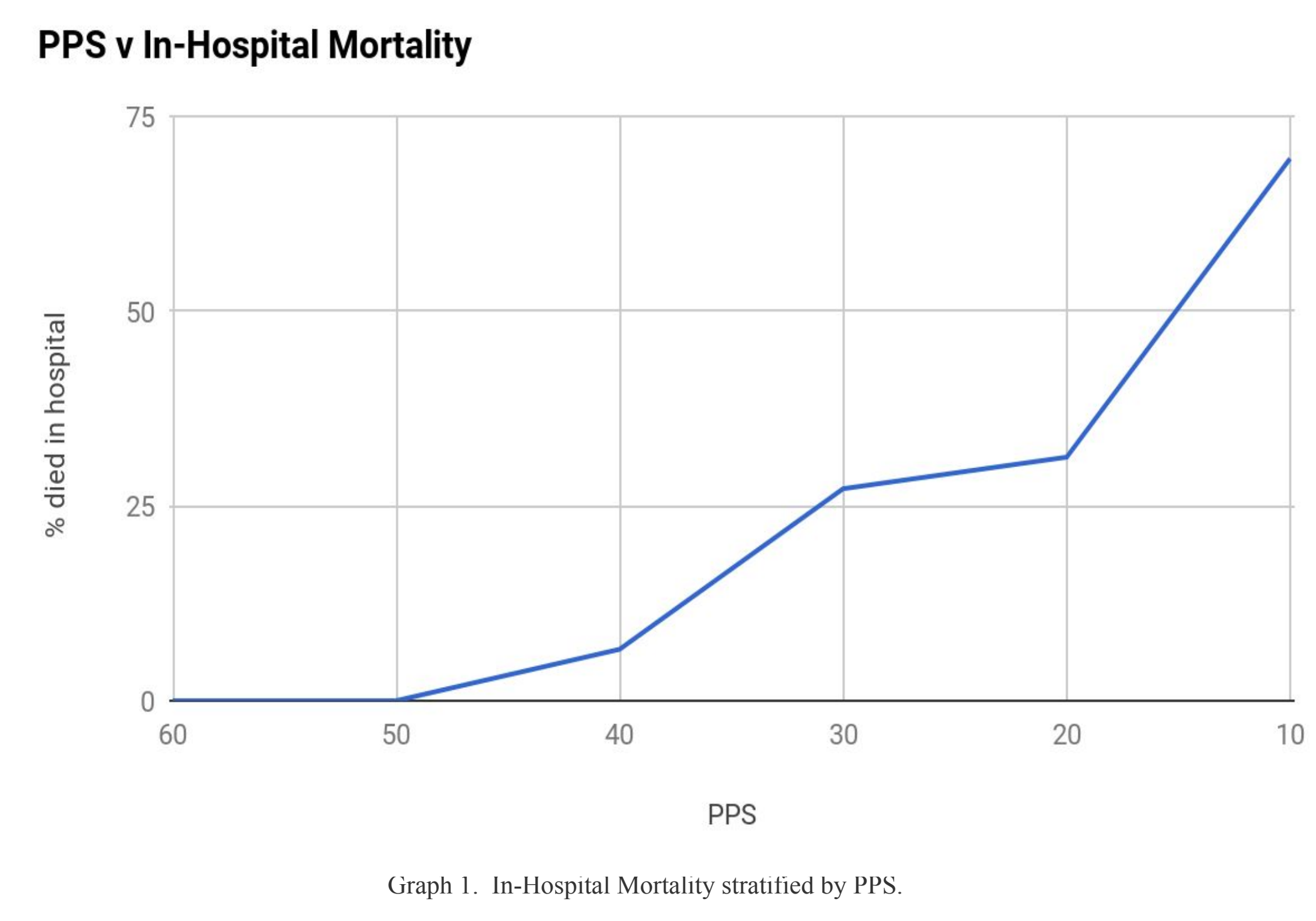

Discussion

- Analysis of this patient population showed that worsening PPS correlates with worsening MELD

- PPS may offer a complementary means of predicting mortality and evaluating transplant candidacy

- PPS may also help hepatologists to evaluate more objectively the functional status of ESLD patients

- In the future, Palliative Care may play an increasingly important role in ESLD symptom management and transplant evaluation 